\title{
Oxidative stress markers and C-reactive protein in end-stage renal failure patients on dialysis
}

\author{
Elisabeth C. Samouilidou • Eirini J. Grapsa • \\ Ioannis Kakavas · Antonios Lagouranis · \\ Basilis Agrogiannis
}

Published online: 27 September 2007

(C) Springer Science+Business Media B.V. 2007

\section{Erratum to: Int Urol Nephrol (2003) 35:393-397 \\ DOI 10.1023/B:UROL.0000022846.83505.3f}

In the article "Oxidative stress markers and C-reactive protein in end-stage renal failure patients on dialysis" by Elisabeth C. Samouilidou, Eirini J. Grapsa, Ioannis Kakavas, Antonios Lagouranis and Basilis Agrogiannis, published in International
Urology and Nephrology-issue 35(3), pages 393397, Fig. 2 was incorrect. Please find the correct figure below.

The online version of the original article can be found under doi: 10.1023/B:UROL.0000022846.83505.3f

E. C. Samouilidou

Biochemical Department, Athens, Greece

E. J. Grapsa $(\bowtie) \cdot$ A. Lagouranis

Renal Unit 'Alexandra' Hospital, 80, Vas. Sophias Str.,

Athens 11528, Greece

e-mail: egrapsa@teledomenet.gr

I. Kakavas

Renal Unit ‘Ippokration’ Hospital, Athens, Greece

B. Agrogiannis

Renal Unit 'Areteion' Hospital, Athens, Greece 
Fig. 2 Plasma CRP levels in healthy individuals (NC), peritoneal dialysis (PD) and hemodialysis (HD) patients before and after dialysis.

Columns represent mean values \pm S.E.M.

Significance: $p<0.001$ in HD patients before or after dialysis vs. NC and PD, $p<$ 0.05 in PDpatients vs. NC

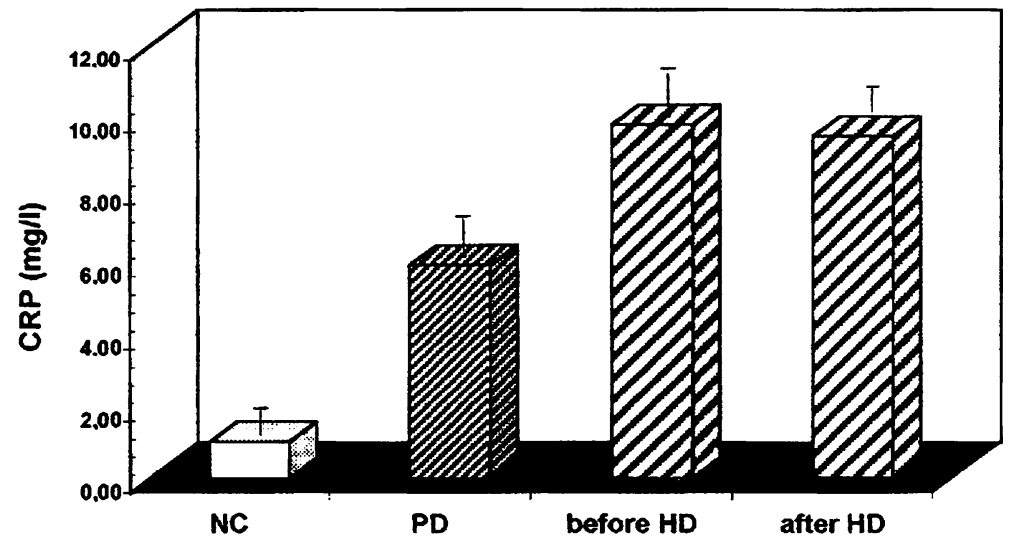

